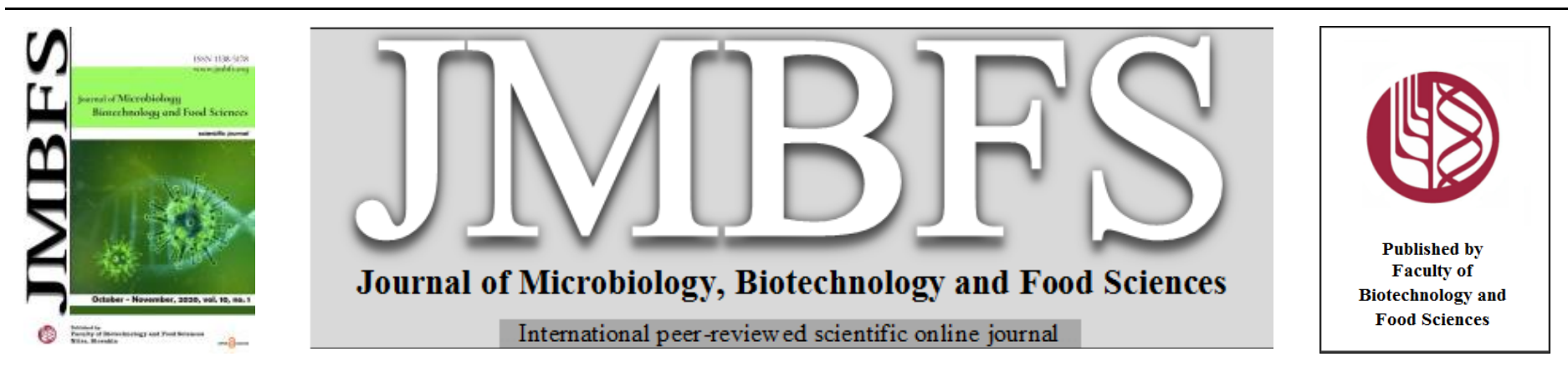

\title{
AUGMENTING THE EFFICIENCY OF SCAFFOLDING IN MEDICAL THERAPIES WITH THE ADVENT OF NANOTECHNOLOGY
}

\author{
Pushpa C. Tomar*1, Tanya Kalrai ${ }^{1}$, Harisha Kohli ${ }^{1}$, Komal Arora $^{1}$
}

$\operatorname{Address(es):~}$

${ }^{1}$ Department of Biotechnology Engineering, Faculty of Engineering \& Technology, Manav Rachna International Institute of Research and Studies, Faridabad, Haryana, (INDIA) -121004 .

*Corresponding author: dr.tomarpushpa@ rgmail.com , pushpa.fet@mriu.edu.in

doi: $10.15414 / j m b f s .2020 .10 .2 .273-278$

\section{ARTICLE INFO}

Received 16. 12. 2019

Revised 13. 6. 2020

Accepted 26. 6. 2020

Published 1. 10. 2020

\section{Review \\ OPEN $\partial_{\text {ACCESS }}$}

\begin{abstract}
The art of manipulating materials on atomic or molecular scales that give rise to nano sized structures and devices is dynamically pioneered and instituted into the world by the name nanotechnology. The field of nanotechnology has ratified its command and is intensifying quickly with its ongoing work in the design, characterization, synthesis, and application of materials and systems by controlling shape and size at nanometer scale. Towards solving the problem of biology and medicine, many efforts have been focused in the direction of the use of nanostructures. This study starts with the main highlights of the types of Nanoscaffolds, surface modification of these scaffolds, applications of Nanoscaffolds in tissue regrowth and terminates with interaction of cells with scaffolds. We have multiple minds all around globe as a result having different perspectives of using these novel technologies in the domain of medical treatment and diagnosis. However, there are many ethics that arose with any new technology amongst supporters and opponents but now is the time to embrace the changes and not been clung to the old ways. So, let us welcome these novel technologies which pave the way for trimming down much of our problems.
\end{abstract}

Keywords: Nanoscaffolds, Nanostructures, Nanotechnology, Tissue Engineering, Treatment

\section{INTRODUCTION}

A multidisciplinary approach, Tissue Engineering designed with an objective of regenerating damaged tissues by developing a substitute mimicking the biological environment for restoring, maintaining and improving the function of tissue (Langer, 2000; Atala, 2004; Bonassar and Vacanti, 1998).

Approaches for the development of engineered tissue include -

scaffolds which acts a support system for the cell where cells are seeded in vitro and then the cells release matrix to produce the foundations of a tissue for transplantation. Use of scaffolds to be employed for growth factor, meaning when scaffolds are combined with growth factors, it results in the formation of tissue throughout matrix by the recruitment of body's cell at the site of scaffolds. Scaffold matrices are used to fill up the void present in between of tissue; to structurally support the tissue and to transport/deliver cells or growth factors that upon transplantation possess the ability to develop tissue (Martin $\boldsymbol{e t}$ al., 2004). Tissue engineering triad referred to the trio of cells, signals and scaffold which provides a standard for tissue development

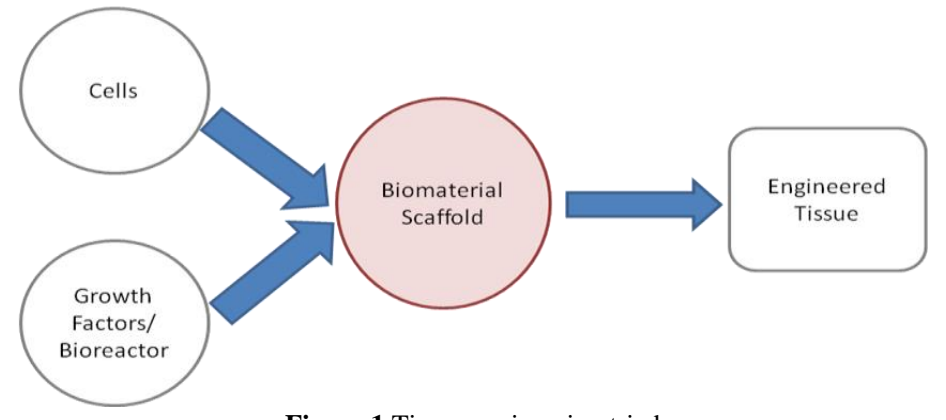

Figure 1 Tissue engineering triad

Designing of scaffold and its fabrication are the main stand back of tissue engineering and regeneration medicines, contributing significantly in the areas of biomaterial research (Langer and Vacanti,1993). Scaffolds are described as the biomaterials that are porous, act as pillar for 3-D tissue development. They are designed in such a way that they mimic the same microenvironment as that of the native cellular tissue and go serve certain functions such as promoting interactions between the cell and biomaterial, adhesion of cell and deposition of ECM; promoting survival, proliferation and differentiation of cell by allowing sufficient amount of gases, nutrients and other regulatory factors to be transported to the cell; controlling the biodegradability date; minimizing the toxicity and inflammation rate in vivo (Langer and Tirrell,2004). For the he scaffolds to be function properly and regulate behavior the cell, it should have the same microenvironment as that of native cell (Goldberg et al., 2007).

ECM surrounds the cell within tissue characterized by well-organized nanofibers (Stevens and George, 2005). Providing cell support and directing the behaviour of the cell are the important functions of this internal nano organization. Storing, releasing, activating biological factors, cell-cell interaction are the additional functions of ECM (Taipale and Keski-Oja, 1997) Thus, it's important to maintain the bifunctionality and complexity of ECM that can be possible by designing and fabricating at the nanoscale which mimic the microenvironment as that of the native ECM (Goldberg et al., 2007).

\section{Types of Nanoscaffolds}

Nanoscaffolding is extremely important in the development in tissue regrowth and regeneration. The method requires making Nanoscaffolds; a 3D microstructure of ultrafine fibers providing a microenvironment in which cells can grow, divide and recreate damage tissue. The properties of the Nanoscaffold are evidently determined by the method of fabrication of the scaffold and the material used to do this. Just like different reactions have different catalyst, the engineering of different tissues requires different Nanoscaffolds. This is due to the surface chemistry exhibited by the scaffolds (Harindi Loku Waduge, 2011) Some part of this review will have few types of Nanoscaffolds discussed along with their fabrication technique and related applications.

\section{Oxide Nanoscaffolds}

Fabrication of oxide Nanoscaffolds takes place on the substrate of pure titanium consists of tin, chromium, and niobium; creating oxide like surface by their deposition following annealing. The most commonly used metal that serves the 
purpose of devices used in load bearing like artificial hip joint stems is titanium and its alloys. Resistance to corrosive nature, biocompatibility with cell and high strength to weight ratio are some of the characteristic features of titanium that make it suitable to be used as a biomaterial (Albrektsson et al.,1981). These attractive features of titanium are due to the presence of an oxide layer that helps in creating the direct contact with the bone tissue and halts the undesirable fibrous tissue formation around the biomaterial.

\section{Cellulose Acetate Nanoscaffolds}

Chemical conversion of cellulose yields a product cellulose acetate Electrospinning is one of the methods for the fabrication into structures as Nanoscaffolds (Chainoglou et al., 2016). Electrospinning cellulose acetate nanofiber has many applications that includes restricted movement of bioactive materials; cell culture; application in tissue engineering (Konwarh et al., 2013). In addition to it, integrity of calcium acetate Nanoscaffolds can be improved by binding with polymers like poly (butyl acrylate) and promote cell growth, cell interaction and electrical functionality (Baek et al., 2011) Another application of calcium acetate Nanoscaffolds is in heart valve tissue engineering where the deposition of calcium acetate Nanoscaffolds onto aortic heart valve enhances growth of cell. Use of bioactive molecules such as TGD peptides and laminins provides the biocompatibility, enhancing endothelization of heart valves and prevents thrombosis

\section{Fibrinogen and fibrin based micro and Nanoscaffolds}

They are non-immunogenicity based Nanoscaffolds and can mimic the structure of the native tissue and can provide a perspective alternative to the tissues and organs that are damaged. Fibrinogen is a $340 \mathrm{kda}$ molecular weight protein found in blood plays a significant role in coagulation and thrombogenesis. Scaffolds of Fibrinogen and Fibrin possess a high cell seeding efficiency, uniformity in cell distribution. The cells then release ECM and then proliferate, move and differentiate into specific tissues/organs. Fibrinogen provides a 3-D, structura and non- textured contact surface for the attachment of cells and their proliferation which then provides a matrix like network for cell signaling and cell- cell interactions (Sell et al., 2010). Release of ECM by Fibrinogen and Fibrin based scaffolds provides a structural based support to the connective tissues like cartilage, bones, ligament, nerves (Meinhart et al., 1999; Sahni and Francis, 2000; Park et al., 2009; Kalbermatten et al., 2008; Gorodetsky et al., 1999). Due to their easy formulation into various structural scaffolds, they are used in diverse applications of tissue engineering (Rajangam et al., 2011;
Rajangam et al., 2012; Swartz et al., 2005; Rejinold et al., 2010; Wnek et al., 2002; Rowe et al., 2007). They have an application in cancer therapy. Fibrinogen and Fibrin based Nanoscaffolds can halt the growth of the cancerous cell progression. This inhibition results by abolishing the excess of coagulation in and around cancerous tissues (Costantini and Zacharski, 1992).Other applications include orthopedic applications (bone repair/ regeneration), promoting viability and cartilage structure, wound healing activity (Patel $\boldsymbol{e t}$ al., 2010; Ishimura $\boldsymbol{e t}$ al., 1997; Marimuthu and Kim, 2009; Clark et al., 1982; Gailit et al., 1997).

\section{Aluminium Oxide Nanoscaffolds}

Aluminium oxide Nanoscaffolds involved actively in promoting the cell interactions. The skin cells initially seeded on the membrane of the Nanoscaffold where these cells can proliferate forming a confluent layer. The confluent layer can then remove from the anodic aluminium oxide membrane and applied to wound part directly. This would have an advantage of easy exchange of gases or fluids through the bank channel and the prevention of infection caused by microsized bacteria. This type of Nanoscaffold used in bone implants, can conform various body shapes, skin tissue engineering (Parkinson et al., 2009).

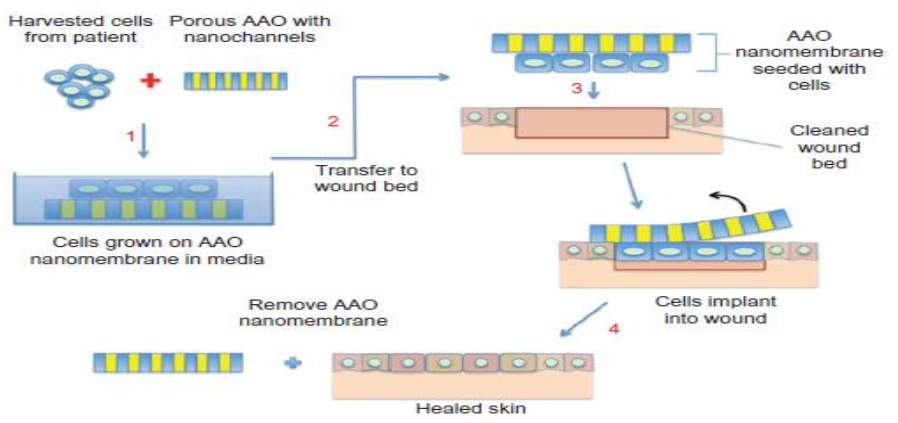

Figure 2 Schematic representation of the anodic Aluminum Oxide (AAO) membrane used as a 'band-aid technique' for skin tissue engineering. (Poinern Gérrard et al., 2011)

Table 1 The summary depicting the distinguishing features of the types of Nanoscaffolds

\begin{tabular}{|c|c|c|c|c|c|}
\hline $\begin{array}{l}\text { Nanoscaffold } \\
\text { material }\end{array}$ & $\begin{array}{c}\text { Fabrication } \\
\text { Technique }\end{array}$ & Strength & Porosity & Biodegradability & $\begin{array}{c}\text { Application } \\
\text { example }\end{array}$ \\
\hline Oxide Nanoscaffolds & Substrate fabrication & $\begin{array}{c}\text { Resistance to corrosive } \\
\text { nature, biocompatibility } \\
\text { with cell, high strength to } \\
\text { weight ratio }\end{array}$ & $\begin{array}{l}\text { Porous structure aid in } \\
\text { tissue regeneration. Eg- } \\
\mathrm{TiO}_{2}\end{array}$ & $\begin{array}{l}\text { Biodegradable when } \\
\text { incorporated } \\
\text { with polymer }\end{array}$ & $\begin{array}{l}\text { Neural tissue } \\
\text { engineering }\end{array}$ \\
\hline $\begin{array}{l}\text { Cellulose } \\
\text { Acetate Nanoscaffolds }\end{array}$ & $\begin{array}{l}\text { Scaffold Fabrication } \\
\text { with Electrospray } \\
\text { Deposition System }\end{array}$ & $\begin{array}{l}\text { Bio compatible with cell, } \\
\text { exhibiting } \\
\text { cell viability, good } \\
\text { physicochemical } \\
\text { morphological and non- } \\
\text { cytotoxic properties. }\end{array}$ & $\begin{array}{l}\text { Porous which makes it } \\
\text { suitable to use in } \\
\text { separation of some } \\
\text { organic substances in } \\
\text { aqueous solution. }\end{array}$ & $\begin{array}{c}\text { High degree of } \\
\text { biodegradability. }\end{array}$ & $\begin{array}{l}\text { Heart Valve } \\
\text { Tissue } \\
\text { Engineering }\end{array}$ \\
\hline $\begin{array}{l}\text { Fibrinogen and fibrin- } \\
\text { based Nanoscaffolds }\end{array}$ & $\begin{array}{c}\text { Microspheres, } \\
\text { microbeads, } \\
\text { microfibers, } \\
\text { nanoparticles, } \\
\text { nanofibers, hydrogels } \\
\text { and } \\
\text { electrospinningmethod } \\
\mathrm{s}\end{array}$ & $\begin{array}{l}\text { Non immunogenicity, ability } \\
\text { to mimic the organization of } \\
\text { native tissue, efficient cell } \\
\text { seeding, uniformity in } \\
\text { distribution of cells. }\end{array}$ & $\begin{array}{l}\text { Pore structures can aid } \\
\text { cell attachments, } \\
\text { cell-matrix interactions, } \\
\text { and nutrient/waste } \\
\text { metabolite transport. }\end{array}$ & $\begin{array}{l}\text { Biodegradable polymer } \\
\text { carriers }\end{array}$ & $\begin{array}{l}\text { Cancer therapy, } \\
\text { Nerve tissue } \\
\text { regeneration, Bone } \\
\text { and cartilage } \\
\text { tissue } \\
\text { regeneration, } \\
\text { Vascular tissue } \\
\text { regeneration, Skin } \\
\text { tissue regeneration }\end{array}$ \\
\hline $\begin{array}{l}\text { Anodic aluminium } \\
\text { oxide Nanoscaffold }\end{array}$ & $\mathrm{Al}$ anodization & $\begin{array}{l}\text { Involved actively in cell } \\
\text { interactions. }\end{array}$ & $\begin{array}{l}\text { Being able to control } \\
\text { the pore size and } \\
\text { porosity of the AAO } \\
\text { scaffold structure } \\
\text { enables the surface of } \\
\text { material to be tailored to } \\
\text { a specific tissue } \\
\text { engineering application }\end{array}$ & $\begin{array}{l}\text { Non-biodegradable and } \\
\text { have to be surgically } \\
\text { removed after use. }\end{array}$ & $\begin{array}{c}\text { Used as cell } \\
\text { culture substrate } \\
\text { for tissue } \\
\text { engineering } \\
\text { application such as } \\
\text { the bio artificial } \\
\text { liver. } \\
\text { Skin tissue } \\
\text { engineering }\end{array}$ \\
\hline
\end{tabular}

Surface Modification of Nanoscaffolds

Adjusting the properties of the surface topology helps in enhancing the endothelialization and in reducing thrombosis. Some of the surface modification techniques include:
Surface Roughening

This technique of surface modification used to increase the surface area of implant; enhance the adhesion of cell by restricting their movement (Pavithra and Doble, 2008; Lyu et al., 1999; Curtis and Wilkinson, 1997; Meredith et 
al., 2003). In this modification the surface topology is done without using the chemicals (Shadpour and Allbritton, 2010). Surface roughness can be increased using oxygen of argon plasma deposition for polymers which leads to increase in cell adhesion; increases wound healing and biocompatibility by plasma deposition in SMP based stents (Pavithra and Doble, 2008; Fare et al., 2005) Surface roughening can also be increased by etching, sanding, polishing and micro blasting (Martinez and Chaikof, 2011; Ikada, 1994).

\section{Surface Patterning}

This is more efficient way of surface modification as compared to surface roughening. Patterning on nano- metal surfaces increases the attachment of endothelial cells, which leads to the increased density of cell on surface and desired healing (Martinez and Chaikof, 2011; Khang et al., 2008; Ranjan and Webster, 2009). Di- block copolymer grafts can be used for patterning, forming patterns of nano size on solid surfaces by attaching (physically or chemically) Patterns are formed on the surface through the technique of photolithotrophy which causes the surface to be exposed for photo irradiation (Nie and Kumacheva, 2008; Xu et al., 2004; Kane et al., 1999). Self-assembled monolayer is another technique of creating patterns which promotes cell attachment and organization, the properties needed to maintain the biocompatibility of stent (Ma et al., 2007; Zhang et al., 1998; Mrksich and Whitesides, 1996).

\section{Chemical modification of the surface}

Use of chemicals to modify the surface topology but without altering its bulk properties is chemical modification. This technique attempts to enhance the performance of the material by altering it chemically. Chemical vapour deposition, plasma vapour deposition, grafting techniques are some of the methods of chemical alteration (Martinez and Chaikof, 2011; Lee et al., 2007) Plasma immersion ion implantation technique for metal helps in reducing the extent of corrosion, increases hardness of the surface, slows down wear and tear using acetylene, nitrogen or oxygen (Chu, 2007). In chemical vapour deposition, a thin film is deposited onto surface of biomaterials by utilization of plasma or other bioactive chemicals rendering the surface altered (Lahann et al., 2002 Favia and Dagostino, 1998). This method of chemical modification is famous for blood compatibility due to non-fouling characteristic features of the deposited film (Favia and Dagostino, 1998). Plasma vapour deposition techniques such as matrix assisted pulsed laser evaporation results in the repos of materials, either organic of biologicals onto the blood contacting surface leads to chemically alteration of the surface (Martinez and Chaikof, 2011). Self-assembled monolayers increase the hydrophobicity/hydrophobicity by the addition of functional groups to the surface.

\section{Interaction of Cells with Scaffolds}

\section{Attachment}

It is the initial step in tissue development as most cells require anchorage for proliferation, migration and differentiation (Alberts et al., 2002). Type 1 collagen acts as an anchor protein for many of the tissues in an early stage of development (Kadler, 2004). After that other proteins came into play where they combine with type 1 collagen forming the native ECM. Mature ECM then mediated the attachment, migration, proliferation and differentiation of cells There is an attempt of making the artificial ECM's that mimic the native ECM structure. Fibronectin, vitronectin and laminins are some of the important attachment/anchored proteins that have the ability to adsorb to the Nanoscaffolds at levels 2.6 to 3.9 times higher than solid walled scaffolds (Woo et al., 2003) Additionally, this adsorption was found to be selective and could not be explained by the surface area alone of the nano-fibrous scaffold (Woo et al. 2003). In one study it has been observed that the culturing of neonatal mouse osteoblasts showed high expression of integrins that were connected with collagen, fibronectin and vitronectin as compared to solid walled scaffolds. Upregulated $\alpha 2$ integrin expression on the Nanoscaffold in the absence of collagen fibril formation suggesting the direct cell and Nanoscaffold interaction via $\alpha 2$ integrin (Woo et al., 2007).

In order to achieve desired cell adhesion but repel unwanted attachment, surfaces of scaffold should not adhere to hyaluronan, polyethylene oxide (Liu et al., 2002), PEG, Glycocalyx (Holland et al., 1998), antibacterial with silver or $\mathrm{N}$ alkylated poly (vinyl pyridine) coatings, and bio adhesive with RGD peptide insertion, growth factor attachment, other bioactive groups decoration, plasma etching, or other chemical modifications (Sakiyama-Elbert et al., 2001). With designed patterns, the arrangement of the cells in 2-D and 3-D may be obtained (Chaikof et al., 2002). Cell morphology and cellular activities can be managed by patterning as well. By creating specific patterns of surface chemistry and/or texture, cell behaviours can be confined with physical or chemical ultrastructure, which can be used to control cellular activity (Chaikof $\boldsymbol{e t}$ al., 2002).

\section{Proliferation}

For tissue development, migration and proliferation of cells is required so that scaffold is fully occupied by the cells. Scar tissue formation can be reduced if the desired cell type undergoes proliferation more rapidly in vivo. It has been shown on various studies, the ability of different cell types on nano- fibrous scaffolds that have high proliferative activity as compared to normal materials (Chen $\boldsymbol{e t}$ al., 2006; Li et al., 2003; Shih et al., 2006; Schindler et al., 2005; Xu et al., 2004; Lee et al., 2005). Culturing pre osteoblasts on nano-fibrous scaffolds showed more proliferation of cells as compared to solid-walled scaffolds and culturing chondrocytes on nanofiber for 3 weeks showed more proliferation as compared to control (Chen et al., 2006; Li et al., 2003).

\section{Differentiation}

The advancement of cell from one cell type to the specialized cell type is termed as differentiation. Differentiation of neural progenitor, hepatocytes, chondrocytes, osteoblasts can be enhanced by nanofibers (Silva et al., 2004 Yang et al., 2004; Chua et al., 2005; Semino et al., 2003; Li et al., 2003; Chen et al., 2006; Woo et al., 2007). There are markers that expressed when the undifferentiated cells get differentiated into the osteoblastic lineage. Markers like Alkaline phosphatase (early osteogenic differentiation marker); osteocalcin, bone sialoprotein (late osteogenic differentiation marker) have been reported to be upregulated on Nanoscaffolds when compared to controls in culture conditions for the time period of 3 days (in vitro) for early osteogenic markers and for 2 or more weeks for late osteogenic markers (Woo et al., 2007; Li et al., 2005; Chen et al., 2006). Expression of osteocalcin and bone sialoprotein is 7.5 and 1.8 times more on nano fibrous scaffolds as compared to solid walled scaffolds (Chen $\boldsymbol{e}$ al., 2006). Another osteogenic marker, type 1 collagen is the only marker whose expression has been shown to be down regulated on nano fibrous materials as compared to solid walled scaffolds, though type 1 collagen is highly distributed on Nanoscaffolds (Chen et al., 2006; Yoshimoto et al., 2003; Shin et al., 2004). Accelerated maturation of ECM could be the reason for the downregulation of type 1 collagen on Nanoscaffolds. Mineralization of ECM starts as the expression of markers of differentiate bone begins by the cell. Due to the evenly distribution of minerals in Nanoscaffolds, enhanced mineralization has been found on nano fibrous scaffolds as compared to solid walled scaffolds (Chen et al., 2006; Woo et al., 2007; Hosseinkhani et al., 2007). Thus, Nanoscaffolds can create vascularized, mineralized and embedded osteocyte like cells bone tissue.

\section{Integration with tissue and healing}

Healing of sounds is one of the main applications in the field of tissue engineering. Many sound healing skin substitutes are available, however due to problems like wound contraction, formation of scar, and most importantly no of poor integration with host tissue, these substitutes suffer a setback. Tissue engineering is an approach which involves the development of scaffolds as ECM in three-dimensional unit that directs cell adhesion, migration, maturation and differentiation in order to develop a structural and functional tissue. These scaffolds cover the wound; provide a physical protection from external infection and acts as a template for the growth of the dermal fibroblasts and keratinocytes. Different types of materials (natural and artificially synthesized) are used in the fabrication of variety of scaffolds (Zhong et al., 2010). The reason of increased mortality of diabetic patients is poor wound healing. To overcome this, Nanoscaffold based wound dressing came into existence that allows targeted drug delivery. Due to higher surface to volume ratio of the nanoparticles, the interaction with the host tissue or target has been increased and these nanoparticles penetrates the wound very easily thereby improves the wound healing process. Nanoparticles deliver drug in a sustained release manner due to which there is a continuous interaction of bioactive molecules with the target tissue which also enabled the controlled delivery of drug and thus limits the toxicity (Kim et al., 2010; Krausz et al., 2015). Nanoscaffold dressings are used for increasing the healing process and to reduce the total microbial load on the wound. Specifically, cellulose nanofiber dressings incorporated with the nanoparticles of silver showed the anti-microbial effects against E. coli, P aeruginosa and S. aureus (Wu et al., 2014).

\section{Application of Nanoscaffolds in Tissue Re-Growth}

The ability of nano structured Nanoscaffolds in minimizing the microenvironment of the cell which leads to cytoskeleton recognition and initiating the targeted cell signaling is of the considerable effect in the field of tissue engineering and regenerative medicine. Scaffolds that behave same biochemically, mechanically and electrically as native tissue can be nano engineered so that that cell adhesion, proliferation, differentiation and maturation this improves the functionality of cell and growth of tissue (Yang et al., 2014). Nano-patterning, self- assembly, electrospinning, conjugation of adhesion motifs to the matrix backbone or sulfating the matrix backbone are some of the techniques of fabricating ECM like organization (Kim et al., 2010). Integration of nanomaterials such as nanowires, carbon nanotubes and nanoparticle can 
easily modify the properties of ECM like organization (Dvir et al., 2011) Development of a hybrid hydrogel, electrically conductive in nature based on gold nanoparticles can boost the functions of cardiomyocytes (You et al., 2011) Surface topographical features of the Nanoscaffold provide the cell a desired surface for migration, proliferation, and differentiation thereby directing the behaviour of cell. Human mesenchymal stem cells can be differentiated towards adipocytes upon variations in these cell adhesion substrate nano surface topologies (Ahn et al., 2014). One study reported the more growth and retention of transplanted heart cells and their interaction with the target tissue after the incorporation of polyethylene glycol based Nanoscaffold in a model of rat having myocardial infarction (Kim et al., 2012). Also, the adhesion and differentiation of adipose stem cells from human enhanced after the coating of a graphene (oxide layer) on a glass slide (Kim et al., 2013). Controlled release of bioactive constituents is also one of the applications of Nanoscaffolds. Polymeric scaffolds offer many potential biological activities with the wide range of chemistry and biocompatibility due to which they are involve in organ substitution and tissue engineering applications like heart valves, arteries, skin and cartilage, pancreas, liver, bladder, corneas, nerves and other soft tissues (Dhandayuthapani $\boldsymbol{e t}$ al. 2011; Mayer et al., 1997; Eaglstein and Falanga, 1998; Tziampazis and Sambanis, 1995; Mayer et al., 2000; Oberpenning et al.,1999; Germain et al. 1999; Mohammad et al., 2000; DiEdwardo et al., 1999). Funda et al., reported the the use of nanoscaffolds in alveolar bone and tooth regeneration (Funda $e$ al., 2020)

\section{CONCLUSION}

This paper demonstrated and presented the significance of Nanoscaffolds in the field of medical treatments and therapies. The growth and many recent developments in the field of nanotechnology allow the inventions of many new materials and techniques that mimic the cell microenvironment as well as ensuring some strategies for the scaffold creation in three dimensions. However, the design and fabrication of a biodegradable scaffold that possess desirable characteristics such as surface chemistry, desired cell attachment, their proliferation and differentiation is the key challenge in the field of tissue engineering. Due to its small-scale size, the interest in modification in the principles of nanotech could be very effective in developing the implants of new design, high quality and of good performance. Although the techniques for scaffold modification are sensitive to various processing parameters (like high energy surfaces, cell density etc.). Conclusively, this review clearly briefs the multidisciplinary approach of Nanoscaffolds, their types, structure, interaction and applications in the field of tissue engineering that could lead to various innovative creations in future.

Acknowledgments: We would like to acknowledge Dr. O.P. Bhalla Centra Library, Manav Rachna International Institute of Research and Studies for their valuable support.

\section{REFERENCES}

Ahn, E. H., Kim, Y., Kshitiz, An, S. S., Afzal, J., Lee, S., ... Levchenko, A (2014). Spatial control of adult stem cell fate using nanotopographic cues. Biomaterials, $35(8)$,

$2401-2410$

http://dx.doi.org//10.1016/j.biomaterials.2013.11.037

Alberts, B., Johnson, A., Lewis, J., Raff, M., Roberts, K., \& Walter, P. (2007) Molecular Biology of the Cell. http://dx.doi.org/10.1201/9780203833445

Albrektsson, T., Brånemark, P.-I., Hansson, H.-A., \& Lindström, J. (1981). Osseointegrated Titanium Implants:Requirements for Ensuring a Long-Lasting, Direct Bone-to-Implant Anchorage in Man. Acta Orthopaedica Scandinavica, 52(2), 155-170. http://dx.doi.org/10.3109/17453678108991776

Atala, A. (2004). Tissue Engineering and Regenerative Medicine: Concepts for Clinical Application. Rejuvenation Research, 7(1), 15-31. http://dx.doi.org/10.1089/154916804323105053

Baek, W.-I., Pant, H. R., Nam, K.-T., Nirmala, R., Oh, H.-J., Kim, I., \& Kim, H.Y. (2011). Effect of adhesive on the morphology and mechanical properties of electrospun fibrous mat of cellulose acetate. Carbohydrate Research, 346(13), 1956-1961. http://dx.doi.org/10.1016/j.carres.2011.05.025

Bonassar, L. J., \& Vacanti, C. A. (1998). Tissue engineering: the first decade and beyond. Journal of cellular biochemistry, 72(S30-31), 297-303.

Chaikof, E. L., Matthew, H., Kohn, J., Mikos, A. G., Prestwich, G. D., \& Yip, C M. (2002). Biomaterials and Scaffolds in Reparative Medicine. Annals of the New York Academy of Sciences, 961(1), 96-105. http://dx.doi.org/10.1111/j.1749-6632.2002.tb03057.x

Chen, V. J., Smith, L. A., \& Ma, P. X. (2006). Bone regeneration on computerdesigned nano-fibrous scaffolds. Biomaterials, 27(21), 3973-3979. http://dx.doi.org/10.1016/j.biomaterials.2006.02.043

Chu, P. K. (2007). Enhancement of surface properties of biomaterials using plasma-based technologies. Surface and Coatings Technology, 201(19-20), 8076-8082. http://dx.doi.org/10.1016/j.surfcoat.2005.12.053

Chua, K.-N., Lim, W.-S., Zhang, P., Lu, H., Wen, J., Ramakrishna, S., ... Mao, H.-Q. (2005). Stable immobilization of rat hepatocyte spheroids on galactosylated nanofiber scaffold. Biomaterials, 26(15), 2537-2547. http://dx.doi.org/10.1016/j.biomaterials.2004.07.040

Clark, R. A. F., Lanigan, J. M., DellaPelle, P., Manseau, E., Dvorak, H. F., \& Colvin, R. B. (1982). Fibronectin and Fibrin Provide a Provisional Matrix for Epidermal Cell Migration During Wound Reepithelialization. Journal of Investigative Dermatology, 79(5), 264-269. http://dx.doi.org/10.1111/1523 1747.ep12500075

Costantini, V., \& Zacharski, L. R. (1992). The role of fibrin in tumor metastasis. Cancer and Metastasis Reviews, 11(3-4), 283-290. http://dx.doi.org/10.1007/bf01307183

Curtis, A., \& Wilkinson, C. (1997). Topographical control of cells. Biomaterials, 18(24), 1573-1583. http://dx.doi.org/10.1016/s0142-9612(97)00144-0

Dhandayuthapani, B., Yoshida, Y., Maekawa, T., \& Kumar, D. S. (2011) Polymeric Scaffolds in Tissue Engineering Application: A Review. International Journal of Polymer Science, 2011, 1-19. http://dx.doi.org/10.1155/2011/290602 DiEdwardo, C. A., Petrosko, P., Acarturk, T. O., DiMilla, P. A., LaFramboise W. A., \& Johnson, P. C. (1999). Muscle tissue engineering. Clinics in plastic surgery, 26(4), 647-56

Dvir, T., Timko, B. P., Kohane, D. S., \& Langer, R. (2010). Nanotechnological strategies for engineering complex tissues. Nature Nanotechnology, 6(1), 13-22. http://dx.doi.org/10.1038/nnano.2010.246

Eaglstein, W. H., \& Falanga, V. (1997). Tissue engineering and the development of Apligraf ${ }^{\circledR}$, a human skin equivalent. Clinical therapeutics, 19(5), 894-905 https://dx.doi.org/10.1016/S0149-2918(97)80043-4

Farè, S., Valtulina, V., Petrini, P., Alessandrini, E., Pietrocola, G., Tanzi, M. C. . Visai, L. (2005). In vitrointeraction of human fibroblasts and platelets with a shape-memory polyurethane. Journal of Biomedical Materials Research Part A, 73A(1), 1-11. http://dx.doi.org/10.1002/jbm.a.30193

Favia, P., \& d' Agostino, R. (1998). Plasma treatments and plasma deposition of polymers for biomedical applications. Surface and Coatings Technology, 98(1-3), 1102-1106. http://dx.doi.org/10.1016/s0257-8972(97)00285-5

Funda, G., Taschieri, S., Bruno, G. A., Grecchi, E., Paolo, S., Girolamo, D., \& Del Fabbro, M. (2020). Nanotechnology Scaffolds for Alveolar Bone Regeneration. Materials, 13(1), 201. http://dx.doi.org/10.3390/ma13010201

Gailit, J., Clarke, C., Newman, D., Tonnesen, M. G., Mosesson, M. W., \& Clark, R. A. F. (1997). Human Fibroblasts Bind Directly to Fibrinogen at RGD Sites through Integrin $\alpha v \beta 3$. Experimental Cell Research, 232(1), 118-126. http://dx.doi.org/10.1006/excr.1997.3512

Germain, L., Auger, F. A., Grandbois, E., Guignard, R., Giasson, M., Boisjoly, H., \& Guérin, S. L. (1999). Reconstructed Human Cornea Produced in vitro by Tissue Engineering. Pathobiology, 67(3), 140-147. doi:10.1159/000028064

Goldberg, M., Langer, R., \& Jia, X. (2007). Nanostructured materials for applications in drug delivery and tissue engineering. Journal of Biomaterials Science, $\quad$ Polymer $\quad$ Edition, $\quad 18(3), \quad 241-268$ http://dx.doi.org/10.1163/156856207779996931

Gorodetsky, R., Vexler, A., Levdansky, L., \& Marx, G. (n.d.). Fibrin Microbeads (FMB) As Biodegradable Carriers for Culturing Cells and for Accelerating Wound Healing. Biopolymer Methods in Tissue Engineering, 11-24. http://dx.doi.org/10.1385/1-59259-428-x:11

Harindi Loku Waduge, B. (2011) 'Learning from nature; Tissue engineering using Nano scaffolding', Based on Pathology lectures, 1-9.

Holland, N. B., Qiu, Y., Ruegsegger, M., \& Marchant, R. E. (1998). Biomimetic engineering of non-adhesive glycocalyx-like surfaces using oligosaccharide $\begin{array}{llll}\text { surfactant } & \text { polymers. } & \text { Nature, } & \text { 392(6678), }\end{array}$ http://dx.doi.org/10.1038/33894

Hosseinkhani, H., Hosseinkhani, M., Tian, F., Kobayashi, H., \& Tabata, Y (2007). Bone Regeneration on a Collagen Sponge Self-Assembled PeptideAmphiphile Nanofiber Hybrid Scaffold. Tissue Engineering, 13(1), 11-19. http://dx.doi.org/10.1089/ten.2007.13.11

Ikada, Y. (1994). Surface modification of polymers for medical applications Biomaterials, 15(10), 725-736. http://dx.doi.org/10.1016/0142-9612(94)90025-6 Ishimura, M., Ohgushi, H., Habata, T., Tamai, S., \& Fujisawa, Y. (1997) Arthroscopic meniscal repair using fibrin glue. Part I: Experimental study. Arthroscopy: The Journal of Arthroscopic \& Related Surgery, 13(5), 551-557. http://dx.doi.org/10.1016/s0749-8063(97)90179-1

Kadler, K. (2004). Matrix loading: Assembly of extracellular matrix collagen fibrils during embryogenesis. Birth Defects Research Part C: Embryo Today: Reviews, 72(1), 1-11. http://dx.doi.org/10.1002/bdrc.20002

Kalbermatten, D. F., Kingham, P. J., Mahay, D., Mantovani, C., Pettersson, J., Raffoul, W., ... Terenghi, G. (2008). Fibrin matrix for suspension of regenerative cells in an artificial nerve conduit. Journal of Plastic, Reconstructive \& Aesthetic Surgery, 61(6), 669-675. http://dx.doi.org/10.1016/j.bjps.2007.12.015

Kane, R. S., Takayama, S., Ostuni, E., Ingber, D. E., \& Whitesides, G. M. (1999) Patterning proteins and cells using soft lithography. The Biomaterials: Silver Jubilee Compendium, 161-174. http://dx.doi.org/10.1016/b978-008045154$1.50020-4$

Khang, D., Lu, J., Yao, C., Haberstroh, K. M., \& Webster, T. J. (2008). The role of nanometer and sub-micron surface features on vascular and bone cell adhesion on titanium. Biomaterials, 29(8), 970-983. http://dx doi org/10.1016/i. biomaterials.2007.11.009 
Kim, B. Y. S., Rutka, J. T., \& Chan, W. C. W. (2010). Nanomedicine. New England Journal of Medicine, 363(25), 2434-2443. http://dx.doi.org/10.1056/nejmra0912273

Kim, D.-H., Han, K., Gupta, K., Kwon, K. W., Suh, K.-Y., \& Levchenko, A (2009). Mechanosensitivity of fibroblast cell shape and movement to anisotropic substratum topography gradients. Biomaterials, 30(29), 5433-5444. http://dx.doi.org/10.1016/j.biomaterials.2009.06.042

Kim, D.-H., Kshitiz, Smith, R. R., Kim, P., Ahn, E. H., Kim, H.-N., Levchenko, A. (2012). Nanopatterned cardiac cell patches promote stem cell niche formation and myocardial regeneration. Integrative Biology, 4(9), 1019 http://dx.doi.org/10.1039/c2ib20067h

Kim, D.-H., Lee, H., Lee, Y. K., Nam, J.-M., \& Levchenko, A. (2010). Biomimetic Nanopatterns as Enabling Tools for Analysis and Control of Live Cells. Advanced $\quad$ Materials, 22(41), 4551-4566. http://dx.doi.org/10.1002/adma.201000468

Kim, J., Choi, K. S., Kim, Y., Lim, K.-T., Seonwoo, H., Park, Y., ... Chung, J. H. (2013). Bioactive effects of graphene oxide cell culture substratum on structure and function of human adipose-derived stem cells. Journal of Biomedical Materials Research Part A, 101(12), 3520-3530. http://dx.doi.org/10.1002/jbm.a.34659

Konwarh, R., Karak, N., \& Misra, M. (2013). Electrospun cellulose acetate nanofibers: The present status and gamut of biotechnological applications. Biotechnology Advances, $31(4)$,

$421-437$ http://dx.doi.org/10.1016/j.biotechadv.2013.01.002

Krausz, A. E., Adler, B. L., Cabral, V., Navati, M., Doerner, J., Charafeddine, R. A., ... Friedman, A. J. (2015). Curcumin-encapsulated nanoparticles as innovative antimicrobial and wound healing agent. Nanomedicine: Nanotechnology, Biology and Medicine, 11(1), 195-206. http://dx.doi.org/10.1016/j.nano.2014.09.004

Lahann, J., Balcells, M., Rodon, T., Lee, J., Choi, I. S., Jensen, K. F., \& Langer, R. (2002). Reactive Polymer Coatings: A Platform for Patterning Proteins and Mammalian Cells onto a Broad Range of Materials. Langmuir, 18(9), 36323638. http://dx.doi.org/10.1021/la011464t

Langer, R. (2000). Biomaterials in drug delivery and tissue engineering: one laboratory's experience. Accounts of Chemical Research, 33(2), 94-101. https://dx.doi.org/10.1021/ar9800993

Langer, R., \& Tirrell, D. A. (2004). Designing materials for biology and medicine. Nature, 428(6982), 487-492. http://dx.doi.org/10.1038/nature02388

Langer, R., \& Vacanti, J. (1993). Tissue engineering. Science, 260(5110), 920926. http://dx.doi.org/10.1126/science.8493529

Lee, B., Jiao, A., Yu, S., You, J. B., Kim, D.-H., \& Im, S. G. (2013). Initiated chemical vapor deposition of thermoresponsive poly(N-vinylcaprolactam) thin films for cell sheet engineering. Acta Biomaterialia, 9(8), 7691-7698. http://dx.doi.org/10.1016/j.actbio.2013.04.049

Lee, C. H., Shin, H. J., Cho, I. H., Kang, Y.-M., Kim, I. A., Park, K.-D., \& Shin, J.-W. (2005). Nanofiber alignment and direction of mechanical strain affect the ECM production of human ACL fibroblast. Biomaterials, 26(11), 1261-1270. http://dx.doi.org/10.1016/j.biomaterials.2004.04.037

Lee, H., Dellatore, S. M., Miller, W. M., \& Messersmith, P. B. (2007). MusselInspired Surface Chemistry for Multifunctional Coatings. Science, 318(5849), 426-430. http://dx.doi.org/10.1126/science.1147241

Li, W.-J., Danielson, K. G., Alexander, P. G., \& Tuan, R. S. (2003). Biological response of chondrocytes cultured in three-dimensional nanofibrous poly(? caprolactone) scaffolds. Journal of Biomedical Materials Research, 67A(4), 1105-1114. http://dx.doi.org/10.1002/jbm.a.10101

Li, W.-J., Tuli, R., Huang, X., Laquerriere, P., \& Tuan, R. S. (2005). Multilineage differentiation of human mesenchymal stem cells in a threedimensional nanofibrous scaffold. Biomaterials, 26(25), 5158-5166. http://dx.doi.org/10.1016/j.biomaterials.2005.01.002

Liu, V. A., Jastromb, W. E., \& Bhatia, S. N. (2002). Engineering protein and cell adhesivity using PEO-terminated triblock polymers. Journal of Biomedical Materials Research, 60(1), 126-134. http://dx.doi.org/10.1002/jbm.10005

Lyu, S.-P., Cernohous, J. J., Bates, F. S., \& Macosko, C. W. (1999). Interfacia Reaction Induced Roughening in Polymer Blends. Macromolecules, 32(1), 106 110. http://dx.doi.org/10.1021/ma9810767

Ma, Z., Mao, Z., \& Gao, C. (2007). Surface modification and property analysis of biomedical polymers used for tissue engineering. Colloids and Surfaces B: Biointerfaces, 60(2), 137-157. http://dx.doi.org/10.1016/j.colsurfb.2007.06.019 Marimuthu, M., \& Kim, S. (2009). Survey of the State of the Art in Biomaterials, Cells, Genes and Proteins Integrated into Micro- and Nanoscaffolds for Tissue Regeneration. Current Nanoscience, 5(2), 189-203. http://dx.doi.org/10.2174/157341309788185389

Martin, I., Wendt, D., \& Heberer, M. (2004). The role of bioreactors in tissue engineering. Trends in Biotechnology, 22(2), 80-86. http://dx.doi.org/10.1016/j.tibtech.2003.12.001

Martinez, A. W., \& Chaikof, E. L. (2011). Microfabrication and nanotechnology in stent design. Wiley Interdisciplinary Reviews: Nanomedicine and Nanobiotechnology, 3(3), 256-268. http://dx.doi.org/10.1002/wnan.123
Mayer, J. E., Shin'oka, T., \& Shum-Tim, D. (1997). Tissue engineering of cardiovascular structures. Current Opinion in Cardiology, 12(6), 528-532. http://dx.doi.org/10.1097/00001573-199711000-00005

Mayer, J., Karamuk, E., Akaike, T., \& Wintermantel, E. (2000). Matrices for tissue engineering-scaffold structure for a bioartificial liver support system. Journal of Controlled Release, 64(1-3), 81-90. https://doi.org/10.1016/s01683659(99)00136-4

Meinhart, J., Fussenegger, M., \& Höbling, W. (1999). Stabilization of FibrinChondrocyte Constructs for Cartilage Reconstruction. Annals of Plastic Surgery, 42(6), 673-678. http://dx.doi.org/10.1097/00000637-199906000-00016

Meredith, J. C., Sormana, J.-L., Keselowsky, B. G., García, A. J., Tona, A., Karim, A., \& Amis, E. J. (2003). Combinatorial characterization of cell interactions with polymer surfaces. Journal of Biomedical Materials Research Part A, 66A(3), 483-490. http://dx.doi.org/10.1002/jbm.a.10004

Mohammad, J., Shenaq, J., Rabinovsky, E., \& Shenaq, S. (2000). Modulation of Peripheral Nerve Regeneration: A Tissue-Engineering Approach. The Role of Amnion Tube Nerve Conduit across a 1-Centimeter Nerve Gap. Plastic \& Reconstructive Surgery, 105(2), 660-666. http://dx.doi.org/10.1097/00006534200002000-00027

Mrksich, M., \& Whitesides, G. M. (1996). Using Self-Assembled Monolayers to Understand the Interactions of Man-made Surfaces with Proteins and Cells. Annual Review of Biophysics and Biomolecular Structure, 25(1), 55-78. http://dx.doi.org/10.1146/annurev.bb.25.060196.000415

Nie, Z., \& Kumacheva, E. (2008). Patterning surfaces with functional polymers Nature Materials, 7(4), 277-290. doi:10.1038/nmat2109

Oberpenning, F., Meng, J., Yoo, J. J., \& Atala, A. (1999). De novo reconstitution of a functional mammalian urinary bladder by tissue engineering. Nature Biotechnology, 17(2), 149-155. https://dx.doi.org/10.1038/6146

Park, K.-H., Kim, H., Moon, S., \& Na, K. (2009). Bone morphogenic protein-2 (BMP-2) loaded nanoparticles mixed with human mesenchymal stem cell in fibrin hydrogel for bone tissue engineering. Journal of Bioscience and Bioengineering, 108(6), 530-537. http://dx.doi.org/10.1016/j.jbiosc.2009.05.021

Parkinson, L. G., Giles, N. L., Adcroft, K. F., Fear, M. W., Wood, F. M., \& Poinern, G. E. (2009). The Potential of Nanoporous Anodic Aluminium Oxide Membranes to Influence Skin Wound Repair. Tissue Engineering Part A, 15(12), 3753-3763. http://dx.doi.org/10.1089/ten.tea.2008.0594

Patel, S., Rodriguez-Merchan, E. C., \& Haddad, F. S. (2010). The use of fibrin glue in surgery of the knee. The Journal of Bone and Joint Surgery. British Volume, 92-B(10), 1325-1331. http://dx.doi.org/10.1302/0301620x.92b10.24828

Pavithra, D., \& Doble, M. (2008). Biofilm formation, bacterial adhesion and host response on polymeric implants-issues and prevention. Biomedical Materials, 3(3), 034003. http://dx.doi.org/10.1088/1748-6041/3/3/034003

Poinern, G., Shackleton, Mamum, \& Fawcett. (2011). Significance of novel bioinorganic anodic aluminum oxide nanoscaffolds for promoting cellular response. Nanotechnology, Science and Applications, 11 http://dx.doi.org/10.2147/nsa.s13913

Rajangam, T., Paik, H., \& An, S. S. A. (2011). Development of fibrinogen microspheres as a biodegradable carrier for tissue engineering. BioChip Journal, 5(2), 175-183. http://dx.doi.org/10.1007/s13206-011-5211-3

Rajangam, T., Paik, H.-J., \& An, S.-S. A. (2012). Fabricating Fibrinogen Microfibers with Aligned Nanostructure, as Biodegradable Threads for Tissue Engineering. Bulletin of the Korean Chemical Society, 33(6), 2075-2078. http://dx.doi.org/10.5012/bkcs.2012.33.6.2075

Ranjan, A., \& Webster, T. J. (2009). Increased endothelial cell adhesion and elongation on micron-patterned nano-rough poly(dimethylsiloxane) films. Nanotechnology, 20(30), 305102. http://dx.doi.org/10.1088/0957$4484 / 20 / 30 / 305102$

Rejinold, N. S., Muthunarayanan, M., Deepa, N., Chennazhi, K. P., Nair, S. V., \& Jayakumar, R. (2010). Development of novel fibrinogen nanoparticles by twostep co-acervation method. International Journal of Biological Macromolecules, 47(1), 37-43. http://dx.doi.org/10.1016/j.ijbiomac.2010.03.023

Rowe, S. L., Lee, S., \& Stegemann, J. P. (2007). Influence of thrombin concentration on the mechanical and morphological properties of cell-seeded fibrin hydrogels. Acta Biomaterialia, 3(1), 59-67. http://dx.doi.org/10.1016/j.actbio.2006.08.006

Sahni, A., \& Francis, C. W. (2000). Vascular endothelial growth factor binds to fibrinogen and fibrin and stimulates endothelial cell proliferation. Blood, 96(12), 3772-3778. http://dx.doi.org/10.1182/blood.v96.12.3772.h8003772 3772 3778 Sakiyama-Elbert, S. E., Panitch, A., \& Hubbell, J. A. (2001). Development of growth factor fusion proteins for cell-triggered drug delivery. The FASEB Journal, 15(7), 1300-1302. http://dx.doi.org/10.1096/fj.00-0564fje

Schindler, M., Ahmed, I., Kamal, J., Nur-E-Kamal, A., Grafe, T. H., Young Chung, H., \& Meiners, S. (2005). A synthetic nanofibrillar matrix promotes in vivo-like organization and morphogenesis for cells in culture. Biomaterials, 26(28), 5624-5631. http://dx.doi.org/10.1016/j.biomaterials.2005.02.014

Sell, S. A., Wolfe, P. S., Garg, K., McCool, J. M., Rodriguez, I. A., \& Bowlin, G. L. (2010). The Use of Natural Polymers in Tissue Engineering: A Focus on Electrospun Extracellular Matrix Analogues. Polymers, 2(4), 522-553. http://dx.doi.org/10.3390/polym2040522 
Semino, C. E., Merok, J. R., Crane, G. G., Panagiotakos, G., \& Zhang, S. (2003) Functional differentiation of hepatocyte-like spheroid structures from putative liver progenitor cells in three-dimensional peptide scaffolds. Differentiation, 71(4-5), 262-270. http://dx.doi.org/10.1046/j.1432-0436.2003.7104503.x

Shadpour, H., \& Allbritton, N. L. (2010). In situ Roughening of Polymeric Microstructures. ACS Applied Materials \& Interfaces, 2(4), 1086-1093. http://dx.doi.org/10.1021/am900860s

Shih, Y.-R. V., Chen, C.-N., Tsai, S.-W., Wang, Y. J., \& Lee, O. K. (2006) Growth of Mesenchymal Stem Cells on Electrospun Type I Collagen Nanofibers. Stem Cells, 24(11), 2391-2397. http://dx.doi.org/10.1634/stemcells.2006-0253

Shin, M., Yoshimoto, H., \& Vacanti, J. P. (2004). In Vivo Bone Tissue Engineering Using Mesenchymal Stem Cells on a Novel Electrospun Nanofibrous Scaffold. Tissue Engineering, 10(1-2), 33-41. http://dx.doi.org/10.1089/107632704322791673

Silva, G. A. (2004). Selective Differentiation of Neural Progenitor Cells by HighEpitope Density Nanofibers. Science, 303(5662), 1352-1355 http://dx.doi.org/10.1126/science.1093783

Stevens, M. M. (2005). Exploring and Engineering the Cell Surface Interface Science, 310(5751), 1135-1138. http://dx.doi.org/10.1126/science.1106587

Swartz, D. D., Russell, J. A., \& Andreadis, S. T. (2005). Engineering of fibrinbased functional and implantable small-diameter blood vessels. American Journal of Physiology-Heart and Circulatory Physiology, 288(3), H1451-H1460. http://dx.doi.org/10.1152/ajpheart.00479.2004

Taipale, J., \& Keski-Oja, J. (1997). Growth factors in the extracellular matrix. The FASEB Journal, 11(1), 51-59. http://dx.doi.org/10.1096/fasebj.11.1.9034166 Tziampazis, E., \& Sambanis, A. (1995). Tissue Engineering of a Bioartificial Pancreas: Modeling the Cell Environment and Device Function. Biotechnology Progress, 11(2), 115-126. http://dx.doi.org/10.1021/bp00032a001

Wnek, G. E., Carr, M. E., Simpson, D. G., \& Bowlin, G. L. (2003) Electrospinning of Nanofiber Fibrinogen Structures. Nano Letters, 3(2), 213-216. http://dx.doi.org/10.1021/n1025866c

Woo, K. M., Chen, V. J., \& Ma, P. X. (2003). Nano-fibrous scaffolding architecture selectively enhances protein adsorption contributing to cell attachment. Journal of Biomedical Materials Research, 67A(2), 531-537. http://dx.doi.org/10.1002/jbm.a.10098

Woo, K. M., Jun, J.-H., Chen, V. J., Seo, J., Baek, J.-H., Ryoo, H.-M., ... Ma, P. X. (2007). Nano-fibrous scaffolding promotes osteoblast differentiation and biomineralization. Biomaterials, 28(2), 335-343. http://dx.doi.org/10.1016/j.biomaterials.2006.06.013

Wu, J., Zheng, Y., Song, W., Luan, J., Wen, X., Wu, Z., ... Guo, S. (2014). In situ synthesis of silver-nanoparticles/bacterial cellulose composites for slowreleased antimicrobial wound dressing. Carbohydrate Polymers, 102, 762-771. http://dx.doi.org/10.1016/j.carbpol.2013.10.093

$\mathrm{Xu}, \mathrm{C}$. (2004). Aligned biodegradable nanofibrous structure: a potential scaffold for blood vessel engineering. Biomaterials, 25(5), 877-886 http://dx.doi.org/10.1016/s0142-9612(03)00593-3

Xu, C., Yang, F., Wang, S., \& Ramakrishna, S. (2004). In vitro study of human vascular endothelial cell function on materials with various surface roughness. Journal of Biomedical Materials Research, 71A(1), 154-161. http://dx.doi.org/10.1002/jbm.a.30143

Yang, F., Xu, C. Y., Kotaki, M., Wang, S., \& Ramakrishna, S. (2004) Characterization of neural stem cells on electrospun poly(L-lactic acid) nanofibrous scaffold. Journal of Biomaterials Science, Polymer Edition, 15(12), 1483-1497. http://dx.doi.org/10.1163/1568562042459733

Yang, H. S., Ieronimakis, N., Tsui, J. H., Kim, H. N., Suh, K.-Y., Reyes, M., \& Kim, D.-H. (2014). Nanopatterned muscle cell patches for enhanced myogenesis and dystrophin expression in a mouse model of muscular dystrophy.
Biomaterials,
$35(5)$
$1478-1486$

http://dx.doi.org/10.1016/j.biomaterials.2013.10.067

Yoshimoto, H., Shin, Y. M., Terai, H., \& Vacanti, J. P. (2003). A biodegradable nanofiber scaffold by electrospinning and its potential for bone tissue engineering. Biomaterials, 24(12), 2077-2082. http://dx.doi.org/10.1016/s01429612(02)00635-x

You, J.-O., Rafat, M., Ye, G. J. C., \& Auguste, D. T. (2011). Nanoengineering the Heart: Conductive Scaffolds Enhance Connexin 43 Expression. Nano Letters, 11(9), 3643-3648. http://dx.doi.org/10.1021/nl201514a

Zhang, M., Desai, T., \& Ferrari, M. (1998). Proteins and cells on PEG immobilized silicon surfaces. Biomaterials, 19(10), 953-960. http://dx.doi.org/10.1016/s0142-9612(98)00026-x

Zhong, S. P., Zhang, Y. Z., \& Lim, C. T. (2010). Tissue scaffolds for skin wound healing and dermal reconstruction. Wiley Interdisciplinary Reviews: Nanomedicine and Nanobiotechnology, 2(5), 510-525. http://dx.doi.org/10.1002/wnan.100 